\title{
Martin Dickinson: 48 Years of Dedicated Service to KU Law
}

Stephen W. Mazza*

The University of Kansas School of Law has a 142-year history. ${ }^{1}$ During that time, several KU Law faculty have devoted forty-plus years of service to the institution and its students. But only one holds the record for the longest period of service: former dean and Robert Schroeder Distinguished Professor of Law, Martin B. Dickinson (1938-2020). From the time he was hired in 1967 to his retirement from the Law School in 2015, an estimated four thousand KU Law students witnessed his skills as a classroom instructor and they, along with thousands more, benefitted from his leadership of and dedication to KU Law. This brief Article includes facts known to many. It also includes anecdotes and occurrences less well-known, particularly to those who met Martin later in his career and after he stepped down as dean. It is a tribute to an individual who spent his professional life in service to his students and colleagues.

\section{A. A NEARLY LIFE-LONG KANSAN}

The Dickinson family's ties to the State of Kansas and its flagship public university are strong. Martin can be forgiven for having been born on the Missouri (rather than the Kansas) side of Kansas City, a circumstance attributable to his parents, Martin B. Dickinson, Sr. and Ruth Van Riper Dickinson. ${ }^{2}$ Both parents, however, earned undergraduate degrees from the University of Kansas and both parents graduated from the University of Kansas School of Law. ${ }^{3}$

\footnotetext{
* Stephen W. Mazza, Dean \& Professor of Law, University of Kansas School of Law. This tribute relies on personal recollections of discussions and interactions with Martin, discussions with Martin's friends, family, and colleagues, and several printed sources. For those who would like read Martin's own take on his 48-year history with KU Law, I recommend Martin Dickinson, 48 Years at KU Law, KU L. MAG. (Fall 2015), available at: https://issuu.com/kulaw/docs/ku-law-magazine-fall-2015 [https://perma.cc/6ECX-6Z9X].

1. At a Glance, KU SCH. OF L., http://law.ku.edu/glance [https://perma.cc/KK9L-CHUT] (last visited Oct. 9, 2020).

2. Martin Dickinson Obituary, LAWRENCE JOURNAL-WORLD (Jan. 8, 2020), https://obituaries.ljworld.com/obituaries/ljworld/obituary.aspx?n=martin-dickinson\&pid=194961505 [https://perma.cc/FEU7-2ZQF] [hereinafter Dickinson Obituary].
}

3. Id. 
Martin also received his undergraduate degree in Political Science from KU, as did his wife, Mary Ann Mize, a native of Salina, who he met while at KU. ${ }^{4}$ The newly married couple moved to California where Martin earned a master's degree in Political Science from Stanford. ${ }^{5}$ They then moved to Ann Arbor, Michigan where Mary Ann completed a master's degree in Chemistry and Martin completed his law degree at the University of Michigan Law School, graduating in $1964 .{ }^{6}$ While at Michigan, Martin served as the Editor-in-Chief of the Michigan Law Review. ${ }^{7}$

After practicing law at a prominent Denver, Colorado-based law firm, Martin moved back to Lawrence with Mary Ann and joined the KU Law faculty in $1967 .{ }^{8}$ Martin and Mary Ann raised their two children, Jim and

Nancy, in Lawrence. ${ }^{9}$ The Lawrence community mourned the loss of Mary Ann in $1996^{10}$ after a battle with cancer. Martin subsequently married Sallie Francis, who moved to Lawrence from Kansas City. ${ }^{11}$ Until a few months before his passing, and with frequent trips to the Colorado Mountains and the Swiss Alps, ${ }^{12}$ they lived in Lawrence and were fixtures within the community.

\section{B. DEAN Dickinson AND THE DEVELOPMENT OF KU LAW}

Martin became dean of the KU Law School at the age of thirty-three and served in that position from 1971 through $1980 .{ }^{13}$ Thirty-three is a remarkably young age for a law school dean, but Martin's selection proved to be a wise choice for an institution responding to changes in society and the legal market.

\section{The Funding and Construction of "New" Green Hall}

In the wake of the Vietnam War, the Civil Rights movement, and growing concerns for environmental protection, law school enrollments around the nation surged. At KU, law school applications more than
4. $I d$.
5. Id.
6. Id.
7. Id.
8. Id.
9. Id.

10. Id.

11. Id.

12. $I d$.

13. Id. 
doubled between 1970 and 1972. ${ }^{14}$ The KU Law School's historic home, Green Hall (now Lippincott Hall), had all the formal trappings of a building devoted to the law-a classically-inspired portico with fluted columns flanking the entrance. It also stood in the shadow of the bronze sculpture depicting Jimmy Green, the first KU Law dean, which was commissioned from the famed sculptor Daniel Chester French. ${ }^{15}$ What the grand building lacked was adequate space to meet the needs of its growing faculty and student population.

The idea of a new law building may predate Martin's tenure as dean, but he is the individual responsible for bringing the project to fruition. Unlike most new buildings constructed on the KU campus today, which are funded nearly entirely with private giving, "New" Green Hall was funded primarily by the people of the State of Kansas. The story of New Green Hall's construction is best told in Martin's own words:

When I was offered the deanship in May of 1971, I accepted on the condition that a new building would be provided from public funds. In September of 1971, the university published an $\$ 85$ million list of capital construction priorities (\$496 million in 2015 dollars). The law school was nowhere on the list.

In response, I orchestrated an intense lobbying campaign, which was vigorously supported by students, faculty and alumni. By the spring of 1972, we were No. 1 on the list.

Now we had to run a gauntlet to get legislative approval. Topeka boosters and some Washburn alumni argued that the KU and Washburn law schools should be combined and located in Topeka - the seat of government. Wichita boosters, observing the greatly increased demand for legal education, argued that a third law school should be created in Wichita.

The 1973 legislative session would be crucial. I knew that we could not leave the outcome to the unpredictable machinations of legislative

14. Martin Dickinson, 48 Years at KU Law, KU L. MAG. (Fall 2015), https://issuu.com/kulaw/docs/ku-law-magazine-fall-2015 [https://perma.cc/6ECX-6Z9X]. Currently, applications to law schools nationwide have declined nearly 40 percent since 2010. Sheri Qualters, Bar Exam Pass Rates Drop Across the Country, NAT'L L. J. (ONLINE) (Nov. 23, 2015). Law school enrollments nationwide match those of law schools in 1970. Benjamin H. Barton, The Law-School Crash, Chron. OF Higher Educ. (Jan. 3, 2020), https://www.chronicle.com/article/the-law-schoolcrash/?cid=reg_wall_signup\&bc_nonce=tj53rrd494bw5zmex70ne [https://perma.cc/TM6U-MX5F]; see also Jennifer Smith, Law-School Matriculation Plunges to 1970s Levels, MARKETWATCH (Dec. 17, 2013, 3:30 PM), https://www.marketwatch.com/story/law-school-enrollment-plunges-to-1970slevels-2013-12-17 [https://perma.cc/X3D7-KJD8].

15. Mindie Miller, KU Celebrates Jimmy Green Statue's 75th Anniversary (Nov. 18, 1999), http://archive.news.ku.edu/1999/99N/NovNews/Nov18/green.html\#: :text=The\%20Green\%20statue $\% 20$ stands\%20on,in\%20front\%20of\%20the\%20statue [https://perma.cc/V42K-F7H5]. 
debate. So, in the fall of 1972, I visited every lawyer-legislator in his or her hometown. This turned out to be one of the most satisfying experiences in my nine years as dean. I was received with gracious hospitality wherever I went, and every lawyer-legislator - whether a graduate of KU, Washburn or another law school - gave me time to make the case. Perhaps as a result of this effort, the initial appropriation for new Green Hall sailed through the 1973 session without a hitch. We were on our way. ${ }^{16}$

Indeed, President Gerald Ford participated in the dedication of the new building in February of $1978 .{ }^{17}$

The idea of the state legislature funding an academic building seems unlikely in today's climate. Martin understates his involvement in convincing the Kansas legislature at the time to approve funding for New Green Hall. As he traveled the State meeting legislators, he made the argument that the State had an obligation to fund a new home for its flagship public law school. His argument was based, in part, on the central role that the Law School plays in the State. He pointed out to these legislators that the school produces the judges, the prosecutors, the public defenders, and the attorneys who represent individuals and businesses across Kansas. Without the players necessary to ensure that the justice system operates at its highest level, justice itself fails to materialize.

Martin also fails to mention the tremendous amount of thought that he and the designers put into Green Hall's construction. While some observers may be put off by the choice of construction materials, it is, at its core, a student-centered building. This was no accident. Unlike most academic buildings, the design includes no physical barriers or other obstacles that prevent students from accessing their professors' offices. The fundamental expectation that law faculty will interact with students is expressed in Green Hall's design and has led to a climate in the building that promotes collegiality and student success. For that, we have Martin to thank.

\section{Promoting a Changing Student Population}

Martin's role as dean was about much more than bricks and mortar. He took the helm of the Law School at a pivotal time for the institution: A time during which issues of racial and gender equality were at the forefront of the national conversation. He advocated for the advancement of diverse

16. Dickinson, supra note 14, at 12. Martin attributes part of the school's success in obtaining a new building to Fred Six, a 1956 KU Law graduate, who at the time served as president of the Law School's Board of Governors and later as a highly-respected justice on the Kansas Supreme Court. Id.

17. Id. 
and female students and faculty at a time when other law schools ignored or grudgingly accepted the idea.

His efforts to encourage female student enrollment may have been inspired by his mother, Ruth, who graduated from KU Law in 1921, the only woman in her class. ${ }^{18}$ During the years he served as dean, the female student population at KU Law grew dramatically. Whereas the entering class of 1970 (the year before he was appointed dean) included only nine female students, by the time he stepped down as dean in 1981, the entering class included seventy-one female students, representing thirty-five percent of the class. ${ }^{19}$

Not only did he encourage expanded enrollment among female students, he also worked to change existing norms within a legal profession, which rejected the idea of hiring female attorneys, much less making them partners in major law firms. Again, Martin's own words explain it best:

As late as 1973 many of the most prominent firms in Kansas City maintained longstanding policies against hiring women. I and others at KU Law traveled to Kansas City and talked with the leaders of those firms. Our arguments were pragmatic - that female enrollment would inevitably grow and that firms unwilling to hire women would deny themselves some of the best talent available. Many firm leaders responded positively, and the rest is history. ${ }^{20}$

Martin goes on to recount the successes of many KU Law graduates in the 1970s who, as female lawyers, broke barriers to become federal and state judges, partners in major law firms, corporate directors, and chairs of federal government agencies. ${ }^{21}$ In addition, during the decade of the 1970s, the number of female members of the KU Law faculty went from zero to five. ${ }^{22}$

Minority student enrollment at KU Law goes back to its earliest days in the late nineteenth century. ${ }^{23}$ Yet it remained low or oftentimes nonexistent in the succeeding decades. ${ }^{24}$ By 1970, that began to change.

18. Id. at 9 .

19. E-mail from Mason Jackson, Univ. of Kan. Analytics \& Inst. Rsch. to Rachel Zierden, Staff Ed. Kan. L. Rev. (Sept. 16, 2020, 10:35 AM) (on file with U. Kan. L. Rev.).

20. Dickinson, supra note 14 , at 9-10.

21. Id. at $10-11$.

22. Id. at 11 .

23. See, e.g., Aaron Holmes, Early Black Graduates Exemplify How Diversity Makes Us Better, KU L. BLOG (Mar. 3, 2017), https://bloglaw.ku.edu/student-life/early-black-graduates-exemplifyhow-diversity-makes-us-better/ [https://perma.cc/JA7C-CKJC] (recounting the career of Isaac F. Bradley, Sr., KU Law's first Black graduate, class of 1887; and his son, Isaac F. Bradley, Jr., KU Law class of 1917).

24. Dickinson, supra note 14, at 13. 
With Martin at the helm, KU Law began to recruit minority students aggressively during the 1970s, leading to a significant expansion in their numbers. ${ }^{25}$ As dean, Martin also recognized the importance of a diverse law school faculty. While dean, he successfully recruited Marilyn Yarbrough Ainsworth to KU Law, one of the first African-American female law professors in the United States and the very first at KU Law. ${ }^{26}$ According to Martin, Marilyn was, as a native of California, reluctant to make the move to Kansas. He called upon prominent African-Americans within the Kansas bar and within the Lawrence community to convince her that a small Midwestern college town would be a welcoming place for her. Her hiring would add to the Law School's proud history of promoting diversity. She would later become the dean of the University of Tennessee Law School, among the first African American female deans of a major Southern law school. ${ }^{27}$

\section{Expanding the Faculty and the Law School's Scholarly Reputation}

As the Law School's enrollment grew in the 1970s, so did the size of its faculty. Having served as Editor-in-Chief of the Michigan Law Review, Martin was exposed to legal scholarship and understood the important role it played in an institution's reputation. So, following in the footsteps of his predecessor, Dean Jim Logan, Martin stressed to his colleagues the importance of hiring new faculty who would be outstanding classroom teachers, and who also possessed scholarly potential. ${ }^{28}$

During his time as dean, KU Law hired faculty who eventually became nationally-recognized scholars, bringing positive attention to the school. They include Tom McGarity, the author of six influential books on administrative and environmental law and the Joe R. and Teresa Lozano Long Professor at the University of Texas Law School; ${ }^{29}$ Sid Shapiro, one of the country's leading experts in administrative law, who left KU Law after decades of service to become the Frank U. Fletcher Chair in Administrative Law at Wake Forest Law School; ${ }^{30}$ and John Peck, the Connell Teaching Professor at KU Law who is recognized as one of the

\footnotetext{
25. See id.

26. Id.

27. Marilyn Ainsworth Yarbrough, JD, UnIV. OF KAN. EMILY TAYLOR CTR. FOR WOMEN \& GENDER EQUITY, https://emilytaylorcenter.ku.edu/womens-hall-of-fame/yarbrough-marilyn [https://perma.cc/NR3K-C2BN] (last visited Oct. 9, 2020).

28. See Dickinson Obituary, supra note 2.

29. Thomas O. McGarity, THE UnIV. OF TEX. AT Austin SCH. OF LAW, https://law.utexas.edu/faculty/thomas-o-mcgarity (last visited Oct. 16, 2020).

30. Sidney Shapiro, WAKE FOREST L., https://law.wfu.edu/faculty/profile/shapirsa/ (last visited Oct. 16, 2020).
} 
leading water law experts in the world. ${ }^{31}$ By the time he stepped down as dean, a ranking of scholarly productivity among all law schools put KU Law fourth in the nation behind only Stanford, Harvard, and the University of Chicago. ${ }^{32}$ Martin was also responsible for hiring other long-serving and beloved KU Law professors, including Fred Lovitch, Webb Hecker, William (Beke) Westerbeke, and David Gottlieb.

Martin made his own singular contributions to the scholarly life of the Law School and its reputation among academics around the U.S. He was an original co-author of a casebook on federal income taxation with Babette B. Barton from the University of California-Berkeley, Regis W. Campfield from Southern Methodist University, Glenn E. Coven from William and Mary, and Charles H. Gustafson from Georgetown University. ${ }^{33}$ The book remained in print through 19 editions. He is probably better known among academics for his casebook on federal estate and gift taxation. Co-authored with Regis W. Campfield and William J. Turnier from the University of North Carolina, Taxation of Estates, Gifts and Trusts became the leading casebook in the field. ${ }^{34}$ By the time he retired, Martin had published twenty-three editions of the book, which was used at over 120 law and business schools around the nation. ${ }^{35}$ In recognition of his scholarly activities, the Law School awarded Martin the Robert A. Schroeder Distinguished Professor of Law in $1986 .{ }^{36}$

Among a group of leading tax scholars, Martin was chosen by Commerce Clearing House, a well-known legal publisher, to chair the editorial board of Federal Income Tax: Code \& Regulations, Selected Sections, a compilation of Federal income tax code and regulatory provisions. ${ }^{37}$ The book is not a typical example of legal scholarship, but Martin's selection as board chair was a recognition of his standing among tax academics. He continued in that position for thirty years and during that time the book's cover included Martin's name. More importantly, it

\footnotetext{
31. John C. Peck, KU ScH. OF L., https://law.ku.edu/faculty/john-peck (last visited Oct. 16, 2020).

32. Id.; Michael I. Swygert \& Nathaniel E. Gozansky, Senior Law Faculty Publication Study: Comparisons of Law School Productivity, 35 J. Legal EdUC. 373, 389 (1985).

33. Babette B. Barton, Regis W. Campfield, Glenn E. Coven, Martin B. Dickinson, Jr., $\&$ ChaRles H. Gustafson, TAXATION OF INCOME (Babette B. Barton, Regis W. Campfield, Charles H. Gustafson, Richard C. Pugh, Glenn E. Coven, Martin B. Dickinson, Jr., Robert J. Peroni, \& William J. Turnier, eds., 19th ed. 1991).

34. Regis W. Campfield, Martin B. Dickinson, \& William J. Turnier, Taxation of ESTATES, GIFTS AND TRUSTS (West, 24th ed. 2012).

35. Dickinson Obituary, supra note 2.

36. Id.

37. Martin B. Dickinson, Federal Income Tax: Code \& Regulations, Selected SECTIONS (Wolters Kluwer, 2019-2020 ed. 2019).
} 
included his affiliation: The University of Kansas School of Law. ${ }^{38}$ Over that thirty-year period, tens of thousands of law students from around the country saw that affiliation. And whether they recalled it or not-at least for an instant - the KU Law School's name was front and center.

\section{Dedication to the State of KANSAS AND ITS InStitutions}

Martin's devotion to the bar in the State of Kansas led to numerous awards. A fixture at continuing legal education programs around the state, he received the Harrison Tweed Award for Excellence in Continuing Legal Education from the American Bar Association. ${ }^{39}$ For his active involvement in the Kansas Bar, the KBA awarded him two honors: The President's Award for Outstanding Service and the Phil Lewis Medal of Distinction. ${ }^{40}$ And for his extensive service to the State and the University, KU awarded him the Steeples Service to Kansans Award. ${ }^{41}$

Martin was also actively involved in numerous legislative initiatives, leading to changes in trust and estate administration procedures, among others. His last foray in Kansas legislative activities involved amendments to the Kansas income tax, which were enacted in 2012. He argued forcefully against the legislation, which allowed sole proprietors and other business owners to shield 100 percent of their business income from state income tax through a tax deduction. ${ }^{42}$ In a 2012 article in the Kansas Law Review, drafted after the Republican-controlled legislature adopted the legislation, Martin described its likely result: "a Kansas tax system in which all three major taxes-property, sales, and income-have a regressive impact, requiring lower-income Kansans to pay taxes that represent a greater portion of their income than will be paid by upperincome Kansans." 43 He also pointed out the inequity it created between business owners - who could qualify for the deduction - and their own employees - who could not. ${ }^{44}$

For those who knew Martin as a Kansas Republican, his reaction to the legislation may have come as a surprise. But claims that the legislation would stimulate the Kansas economy and lead to an increase in population in the State were, in Martin's opinion, overblown. He predicted,

\footnotetext{
38. Id.

39. Dickinson Obituary, supra note 2.

40. Id.

41. $I d$.

42. Act of May 22, 2012, ch. 135, sec. 12, § 79-32, 117(c)(xx), 2012 KAN. SESS. LAWS 1052 repealed by Act of June 6, 2017, ch. 84, 2017 KAN. SESS. LAwS 823.

43. Martin B. Dickinson, Stephen W. Mazza, \& Michael R. Keenan, The Revolutionary 2012 Kansas Tax Act, 61 U. KAN. L. REV. 295, 341 (2012).

44. Id. at 335 .
} 
accurately, that the legislation would deprive the State of tax revenue and lead to cuts in government services. ${ }^{45}$ He also lamented the fact that the legislation had been billed as a benefit to small businesses, when, in fact, it included no cap that would prevent large businesses from taking full advantage of the benefit. ${ }^{46}$ In the end, his concerns were proven correct and the legislation was repealed. ${ }^{47}$

Importantly, he refused to remain silent in response to developments that he believed would harm the State he and his family called home and the institutions he respected. He spoke eloquently and precisely to state legislators for many years. More often than not, they listened. When they did not, he spoke louder.

\section{A Fundamental Devotion to his Students, AND Vice Versa}

Many of Martin's students knew him as dean, but most knew him simply as professor. As a classroom teacher, he was outstanding and was highly respected by his students. Over the years he received numerous teaching awards from the Law School and the University, including the Chancellor's Award for Excellence in Teaching in 1988, the Immel Award for Teaching Excellence in 1997, and the Kemper Fellowship for Teaching Excellence in 2002. ${ }^{48}$ He was a four-time recipient of the Moreau Award for Student Counseling (1988, 1995, 1997, 2009), a designation made by the students to honor a faculty member who they viewed as an outstanding teacher and mentor. ${ }^{49}$ And more often than not, Martin was selected by the student body to be hooder or marshal at their commencement ceremony.

The numerous testimonials the Law School received upon his retirement and at his passing speak to a professor who was tough and demanding, but truly interested in ensuring that his students absorbed the material. One former student mentioned Martin's effective use of the "football theory"-allowing students to fumble around until they figured out the right answer for themselves.

I sat in with the students when Martin last taught a class at KU Law in

45. Martin Dickinson, Kansas Tax Act Most Regressive in Nation, LAWRENCE J. WORLD (May 27, 2012, 12:00 AM), https://www2.ljworld.com/news/2012/may/27/kansas-tax-act-most-regressivenation/ [https://perma.cc/GLN5-YHMD].

46. Dickinson et al., supra note 43, at 314-15.

47. Act of May 22, 2012, ch. 135, sec. 12, § 79-32, 117(c)(xx), 2012 KAN. SESS. LAws 1052, repealed by Act of June 6, 2017, ch. 84, 2017 KAN. SESS. LAWS 823.

48. Margaret Hair, KU Law Community Mourns Passing of Former Dean, KU TODAY (Jan. 9, 2020), https://today.ku.edu/ku-law-community-mourns-passing-former-dean [https://perma.cc/5TKX-B5DZ].

49. Id. 
2016. I was amazed by his level of organization and the way he balanced the high expectations he had for his students with an understanding that the material was complex and needed further explanation. He was a strong believer that students would achieve a high level of performance if the professor consistently held them to account. It was that consistency that led his students to appreciate, rather than begrudge, the high standards he set for them.

I was also impressed by Martin's ability to commit his students' names to memory. He would arrive on the first day of class and already know every student by name. Some students interpreted this as an intimidation technique on his part. According to his son, Jim, they had it all wrong. Martin put in a lot of time and effort to commit the students' names to memory. The fact that he did so- to connect with them in that way-is impressive. It allowed him to scan the classroom, read students' faces, and if he saw confusion, ask the student by name whether the student needed him to clarify what he had said. It was not an act of intimidation: it was a gesture of respect and a sign that he truly cared about the learning process.

The goodwill he generated among his students is even more remarkable given that his subject matter was tax, an area of the law often considered by law students to be dry and technical. His approach to tax law inspired many of his students to specialize in the area and go on to highly successful careers. And when it came to career advice and assistance, Martin believed he had an obligation to help create opportunities for all his students, regardless of where they stood in the class. Examples of students who were not at the top of their class and who benefitted from his assistance are numerous, but to protect the confidentiality of their grade point averages, I will mention no specific names.

As Martin wrote in the KU Law Magazine in commemoration of his retirement, "[e]very year I am inspired by [my students'] talent, dedication and promise. They always give me hope for the future, and it has been a privilege to play a role in their lives." 50

\section{E. A FinAl Thank You to A TRUE FRIEND AND SUPPORTER}

For an individual so frequently honored by his students and colleagues, Martin was reluctant to accept praise. When it came, however, he accepted it graciously. At his own retirement party, Martin spoke of the milestones achieved by those in attendance, primarily his former

50. Dickinson, supra note 14 , at 9 . 
students, rather than his own accomplishments.

The facts presented in this piece and the tributes it includes may not fully capture Martin's generous nature, particularly towards me and the many former students who remained in touch with him. In my own case, I was drawn to KU Law in large part because of his outreach. Based on just a few interactions with him when I was a candidate for a faculty position, I was assured that he would be an encouraging and generous colleague and mentor. I did not realize at the time that he would become a true friend. He was also a loyal supporter. Having spent decades carefully tending his professional reputation, he generously shared that influence to benefit others. For that, I am truly grateful.

At this retirement party, Martin's former students, his friends, and his admirers generously donated to a fund in his honor. After chatting with him about how the Law School might use that funding, we eventually settled on a teaching award for faculty. Martin made it clear that the students should be given the honor of selecting the award recipient. He carefully crafted the criteria and insisted on procedures that would encourage students to participate in the selection process. At the same time, he wanted to reward those faculty who challenged students to think critically, who set clear learning outcomes, and who were available to students outside of class.

The Martin B. Dickinson Teaching Award stands as a testament to a faculty member who spent his 48 years at KU Law promoting his faculty colleagues and establishing a reputation as an outstanding and caring classroom teacher. It benefits faculty colleagues and honors current students by allowing them to make the award selection. Just as importantly, it ensures that Martin's contribution to KU Law will never be forgotten. 